\title{
Dobrovoljno ropstvo i totalitarnost u distopijskim romanima 20. stoljeća: Status književnosti u Vrlome novom svijetu, 1984. i Fahrenheitu 451
}

AвSTRACt: Štahan Matija, Dobrovoljno ropstvo i totalitarnost u distopijskim romanima 20. stoljeća: Status književnosti $u$ Vrlome novom svijetu, 1984. $i$ Fahrenheitu 451 (Voluntary Servitude and Totalitarianism in Dystopian Novels of the $20^{\text {th }}$ Century: Status of the Literature in Brave New World, 1984 and Fahrenheit 451). "Poznańskie Studia Slawistyczne" 17. Poznań 2019. Publishing House of the Poznań Society for the Advancement of the Arts and Sciences, Adam Mickiewicz Univesity, pp. 253-267. ISSN 2084-3011.

The article thematises the relationship of the will to rule and the will to be ruled in the aforementioned dystopian novels by Aldous Huxley, George Orwell and Ray Bradbury. The first part of the article points out Hannah Arendt's observations on the nature of totalitarianism, the second part deals with the similarities concerning the status of literature in the fictitious totalitarian societies represented in the three novels, whereas the final part exemplifies Arendt's views through Étienne de La Boétie's writings on "voluntary servitude". The conflict between those who want to be ruled and those who want to be free reflects the clash of those who want to annihilate literature and those who want to preserve it.

KEYwORDS: democracy and totalitarianism; voluntary servitude; dystopian novels; book burning

Kad bi se spalile sve knjige, sve što se do sada napisalo, čovjek bi ih napisao još bolje (Borges, 1997, 10).

Rukopisi ne gore (Bulgakov, 1980, 310).

\section{Paradoksi totalitarnosti i demokracije}

Prije upuštanja u razmatranje odnosa totalitarnih i demokratskih elemenata u romanima Vrli novi svijet Aldousa Huxleyja (1932), 1984. Georgea 
Orwella (1949) te Fahrenheit 451 Rayja Bradburyja (1953) potrebno je definirati navedene politološke pojmove, čije značenje nije fiksno i jednoznačno, već ovisno o kontekstu razmatranja i definicijama pojedinih analitičara. „Kad pojam postane tako univerzalno posvećen kao što je danas «demokracija», počinjem se pitati da li on išta znači, jer znači mnogo toga“, ustanovio je T. S. Eliot (2009, 395). Isto se, s oprečnim vrijednosnim konotacijama, može ustvrditi i za pojam kao što je „totalitarnost“. Hannah Arendt definira je nekonvencionalno: ne kao pojedinu ideologiju, nego kao svojevrsni stil obnašanja vlasti, koji u svoje ciljeve može instrumentalizirati različite ideologije. Totalitarni fenomeni, zapravo, ideologiju svode na sredstvo pomoću kojega se održavaju na vlasti: iako se Staljinova i Hitlerova vladavina, kao jedina dva moderna režima koje Arendt vidi totalitarnima (1996, 11-13), temelje na nacionalizmu, socijalizmu i komunizmu, Arendt fenomen totalitarnosti ne tumači imanentnim navedenim ideologijama, nego formom u koju se mogu upisivati različiti ideološki sadržaji.

Definirajući je pojavnošću koja nadilazi ideološke fenomene - koje može iskoristiti, ali se ne može svesti u njihove okvire niti se u njima iscrpiti - Arendt ističe kako totalitarnost karakterizira prešutni ili neprešutni, svjesni ili podsvjesni konsenzus pučanstva obuhvaćenog totalitarnom vladavinom o samopodređivanju ideji koju režim s totalitarnim pretenzijama predstavlja krajnjim ciljem svojega, ali i svega postojanja (Arendt, 1996, 7). Bismo li stoga mogli zaključiti kako je totalitarnost - budući da se temelji na suglasju znatno većeg dijela zajednice negoli je slučaj u bilo kojemu kontekstu koji poimamo demokratskim - ujedno i idealan tip demokracije? Pretpostavimo li, s jedne strane, da je ideal demokracije u što cjelovitijemu konsenzusu, čini se da je tome tako. S druge pak strane, pojmimo li ideju pluralizma kao bît demokracije, onda se točnijom čini ocjena Jacquesa Rancièrea kako se demokracija ne ostvaruje uslijed jednakoga, već različitoga mišljenja onih koji u njoj participiraju; ona je „carstvo ekscesa“ (Rancière, 2008, 15), „djelovanje koje oligarhijskim vladavinama neprestano otima monopol na javni život" (Rancière, 2008, 116), štoviše „anarhijsko «vladanje» koje se ne temelji ni na čemu drugom do odsutnosti svake ovlasti za vladanje“ (Rancière, 2008, 52). Ako, dakle, u demokraciji svi misle jednako, ona tada prerasta u totalitarizam - koji se, ovisno o perspektivi, može činiti vrhuncem demokracije ili njezinom dijametralnom suprotnošću. 


\subsection{Totalitarnost Vrloga novog svijeta, 1984. i Fahrenheita 451}

Iz međuigre jednoumlja i misaonog pluralizma, sile koja tjera na sužanjstvo i „dobrovoljna ropstva“" proizlazi i problematika razlučivanja između utopije i distopije, napose u nekima od najpoznatijih distopijskih romana 20. stoljeća, kao što su Vrli novi svijet, 1984. i Fahrenheit 451. Ovi romani - nastali, kao i glavnina drugih djela koja pripadaju tome žanru, u angloameričkome kontekstu, možda upravo zato što on, povijesno gledano, nikada nije bio totalitarnim - distopijskima se tumače iz vizure čitateljske publike, koja ih je beziznimno protumačila takvima ${ }^{1}$. No iz vizure svojih likova - napose glavnih, razapetih između konformizma i slobodoumlja - pitanje je li društvo gdje se zbiva radnja utopijsko ili distopijsko ponovno dobiva na aktualnosti. Tu podvojenost podcrtava i Margaret Atwood, i sama autorica distopijskoga romana Sluškinjina priča, smještajući Vrli novi svijet i 1984. u tradiciju ne samo književnih djela - poput Gulliverovih putovanja Jonathana Swifta ili Vremenskoga stroja H.G. Wellsa - nego i onih filozofskih, satiričnih ili vjerskih ${ }^{2}$, poput Platonove Države, Utopije Thomasa Morea ili biblijske Knjige otkrivenja, čije autorstvo kršćanska tradicija pripisuje evanđelistu Ivanu (Atwood, 2007).

Navedena djela, posebice ona koja nisu ekskluzivno književna, nerijetko su istovremeno i utopijska i distopijska: Knjiga otkrivenja, primjerice, govori i o vladavini antikrista i o „novome Nebu i Novoj zemlji“

${ }^{1}$ Zanimljivo je primijetiti kako distopijski romani - poput, primjerice, djela znanstvene fantastike - ostavljaju veći trag u široj čitateljskoj javnosti i popularnoj kulturi negoli u znanstvenim ili popularnim pregledima najvećih postignuća književne umjetnosti. Nijedan od tri naslovna romana ne spominje se u Povijesti svjetske književnosti Milivoja Solara, a Harold Bloom i Huxleyja (Bloom, 2003, 1-2) i Orwella (Bloom, 2007, 1) doživljava značajnijim esejistima nego romanopiscima. Iz toga se može izvući pretpostavka kako je distopija idealan književni žanr za književnike koji beletrističku narav svojih djela djelomice narušavaju publicističkim elementima.

${ }^{2}$ Širi raspon neknjiževnih djela koja su u temelju utopijskoga žanra u svojemu ogledu o Orwellovoj 1984. nudi Erich Fromm (1983, 281), navodeći, pored Moreove Utopije, Campanellin Grad sunca (1602), Andreaeov Christianopolis (1619), ali i rane utopijske romane, poput Bellamyjeva Gledajući unatrag: 2000-1887 (1888). Veći broj preteča u užem vremenskome rasponu, to jest isključivo u 19. stoljeću, pronalazi Erika Gottlieb (2001, 43-55) u Čovjekovoj tragediji Imre Madácha (1861) i Braći Karamazovima Fjodora M. Dostojevskog $(1879 / 1980)$. 
(Otk 21,1), kao (rano)kršćanskim varijantama distopije i utopije. Obje navedene vrste, u skladu s time, nastaju u okolnostima koje nisu utopijske niti distopijske, već njihova vremenska preteča, zemljopisno susjedstvo ili oboje; Platonovu Državu ne percipira se isključivo prototipom utopističke pisane riječi, nego je Karl Popper poima „u osnovi istovjetn[om]“ totalitarizmu (Popper, 2003, 78) sa svim negativnim konotacijama koje, neovisno o konkretnoj definiciji, gotovo nužno idu uz taj pojam. Kako nastanak distopijskoga djela $\mathrm{u}$ istinski distopijskome kontekstu nije moguć - pa se i ovaj rad, djelomice na tome tragu, usredotočuje upravo na distopije koje djeluju u smjeru poništavanja književnosti kao takve - tako je i utopijsko djelo u utopiji bespotrebno: u „Platonovoj državi“ Platonova Država ne bi mogla postojati, niti bi, poput Knjige otkrivenja na „novome Nebu i novoj Zemlji“, imala smisla na isti način na koji ga ima u onome što nije „Platonova država“ odnosno „novo Nebo i nova Zemlja“. Iz istoga razloga Vrli novi svijet ne nastaje u Svjetskoj Državi, 1984. u Oceaniji, a Fahrenheit 451 u neimenovanoj inačici SAD-a u kojoj „spaljivači“ (u izvorniku firemen, kao riječ koja inače podrazumijeva vatrogasce) bacačima plamena sustavno iskorjenjuju knjige iz svijeta, ali valja napomenuti kako upravo iz toga razloga djela srodna ovima, uz iznimku onih koja funkcioniraju na razini alegorije, a ne sustavne obrade kakva imaginarnog totalitarizma ${ }^{3}$, ne nastaju ni u Hitlerovom Reichu ili Staljinovu Sovjetskome Savezu, nego u zemljama liberalne demokracije, Velikoj Britaniji i SAD-u.

Prije navođenja konkretnih sličnosti na temelju kojih ovaj rad uspoređuje tri navedena romana, usredotočimo se na njihove općenite sličnosti koje ih svrstavaju u istu romanesknu kategoriju, ali i na one razlike koje upućuju na funkcionalnu raznovrsnost upravo onih elemenata na koje ćemo se kasnije usredotočiti. U sva tri romana, ponajprije, postoje djelatni

\footnotetext{
${ }^{3}$ Roman Mi Jevgenija Zamjatina po svojoj je distopijskoj naravi usporediv s romanima o kojima je ovdje riječ, a njegova pojava 1924. godine ide u prilog Arendtinoj teoriji o staljinizmu - koji u doba objavljivanja Zamjatinova romana, ujedno i godini Lenjinove smrti, još nije uzeo maha - kao totalitarizmu usporedivu jedino s Hitlerovim nacionalsocijalizmom. Začeci svih ključnih elemenata totalitarne diktature, u romanesknome kontekstu preinačene u karakteristike Zamjatinove distopije, prisutni su, međutim, već i u Lenjinovo doba. Primjer romana koji se može čitati i kao kritika sovjetskog režima, a koji nastaje u Staljinovo doba, Bulgakovljevo je nipošto distopijsko djelo Majstor i Margarita.
} 
obrasci onih koji vladaju, a koji se mogu svrstati u kategoriju ophođenja s kolektivom na totalitaran način, kako ga definira, primjerice, Alain de Benoist, opisujući „mentalno ponašanje“ karakteristično za totalitarnost, koje pronalazi u „miješanju dvaju različitih elemenata“; to su, „s jedne strane, manihejska i mesijanska vizija «vjerske» naravi, a s druge krajnji voluntarizam, povezan s bezrezervnim prihvaćanjem vrijednosti modernosti““ (Benoist, 2005, 103).

U tome kontekstu, u sva tri romana djeluju tri srodna glavna junaka i Bernard Marx, i Winston Smith, i Guy Montag sredovječni su muškarci koji žive u megadržavama, u određenoj mjeri otuđeni od (vlastitih) žena, koji u jednome trenutku osjete otpor prema društvenome poretku, te se protiv njega na ovaj ili onaj način pobune. Sličnosti se produžuju i na antagoniste, to jest figure kao što su Nadzornik Mustafa Mond, član Uže Partije O’Brien i zapovjednik spaljivača, kapetan Beatty, koji Marxu, Smithu i Montagu predstavljaju ključne, intelektualno superiorne, autoritativne, a neformalne suparnike, predstavnike institucija kojima su glavni junaci nekoć i sami pripadali, da bi ih se sada odrekli i okrenuli protiv njih - no redom neuspješno, upravo zahvaljujući navedenome nadređenom, nadmoćnome trojcu. Oni su čuvari postojećega poretka te svojevrsni tumači filozofije kolektivna jednoumlja vladajućih opcija u trima romanima, pa se njihove izjave mogu čitati i kao teorijski iskazi o naravi totalitarizama koje zastupaju.

Iz različitih viđenja naravi tipa totalitarnosti koje ključni antagonisti iz Vrloga novog svijeta, 1984. i Fahrenheita 451 zastupaju mogu se iščitati i neke razlike među navedenim romanima, koje se u bitnome svode na načine na koje vlast provodi svoju totalitarnu vladavinu. U Orwellovu romanu taj način je krajnje nasilan, kako na implicitnoj, tako i na eksplicitnoj razini. Jedna od metoda ne samo provedbe nego i poticanja na nasilje perpetuiranje je urbane legende o fantomskome Bratstvu, skupini navodnih disidenata čije istinsko postojanje spada u domenu nepoznatoga, pa čitatelj, kao ni glavni junak, nikada ne doznaje je li riječ o postojećim borcima protiv režima ili o izmišljotini Uže Partije s manipulativnom svrhom fabrikacije žrtvenoga jarca, izmišljenog neprijatelja koji kroz odvraćanje pozornosti od naravi partijske vlasti, kao i institucionalizaciju mržnje („Tjedan mržnje“, svakodnevna „Dvominutna mržnja“), u skladu s načelom mimetičkoga nasilja kako ga definira René Girard, služi kao 
Žarišna točka usmjeravanja netrpeljivosti prema samo jednome pojedincu, tobožnjemu vođi pokreta otpora Emmanuelu Goldsteinu ${ }^{4}$ (cf. Girard, 2003, 72). Moć „zarazne“ mržnje očituje se i u svijesti samoga Winstona Smitha, koji otkriva kako se - unatoč odioznosti koju osjeća spram Velikoga Brata, mitskoga vođe Partije i oceanijskoga diktatora, a koji, poput Goldsteina ili čitava Bratstva, možda i ne postoji - svejedno nerijetko ne može oduprijeti destruktivnome nagonu koji je prisiljen demonstrirati prilikom svakodnevnih mrzilačkih rituala (Orwell, 2008, 16). Suptilniji vid nasilja u 1984. očituje se u sveprisutnosti „telekrana“, uređaja nalik televizorima kroz koje članovi Partije gledaju partijske programe, dok Partija istovremeno, s druge strane, kroz „telekrane“ nadgleda njih (Orwell, 2008, 9).

Za razliku, međutim, od Orwellova romana, vođe Vrloga novog svijeta svoje svevlašće ne temelje na nasilju, nego na manipulaciji užitkom. „Dvojbeno je može li u zbilji politika čizme-na-licu trajati vječno“, napisao je u svojemu pismu Orwellu sâm Aldous Huxley:

Moje je uvjerenje da će vladajuća oligarhija pronaći manje naporne i rastrošne načine upravljanja i zadovoljavanja svoje žudnje za moći, a koji će nalikovati onima koje sam opisao u Vrlome novom svijetu. [...] Vjerujem kako će u sljedećemu naraštaju vladari otkriti da su uvjetovanje djece i narko-hipnoza učinkovitiji instrumenti vladanja od toljage i zatvora, kao i da žudnja za moći navođenjem ljudi na ljubav prema vlastitome ropstvu može biti jednako zadovoljena kao i udarcima što tjeraju na poslušnost. Drugim riječima, čini mi se da je möra 1984. predodređena za preobrazbu u möru koju sam zamislio u Vrlome novom svijetu (Huxley, 2015).

Nešto slično Huxley je primijetio i u predgovoru poslijeratnog izdanja Vrloga novog svijeta:

Vladanje batinama i vodovima za strijeljanje, umjetno izazvanim nestašicama, masovnim zatvaranjima i progonstvima [...] dokazano je kao nedjelotvorno [...]. Stvarno djelotvorna totalitarna država bila bi ona u kojoj svemoćna izvršna vlast političkih glavešina i njihove vojske upravljača kontrolira populaciju robova koje nije potrebno prisiljavati, jer oni vole svoje robovanje. U današnjim totalitarnim državama, zadaća da robovi zavole svoje robovanje dodijeljena je ministarstvima promidžbe, masmedijima i učiteljima (Huxley, 1998, 12).

${ }^{4}$ Thomas Pynchon pretpostavlja kako se iz Goldsteinova imena može iščitati - kao i iz brkate prilike Velikoga brata Staljinova sjenka - odraz Lava Trockog, ali i kako se 1984. ne može svesti na repliciranje sovjetske stvarnosti, nego na projiciranje zamišljenog totalitarizma u moguću budućnost Zapada (Pynchon, 2003.). 
Između manipulacije prisilom, karakteristične za 1984., i manipulacije užitkom, svojstvene Vrlome novom svijetu, Bradburyjev Fahrenheit 451 svojevrsna je kombinacija navedenih elemenata: ako Vrli novi svijet počiva na ekvivalentu Debordove vizije „društva spektakla“, koje se očituje u filmovima za osjetilo dodira u kojima se „osjetilni svijet zamjenjuje izborom slika koje postoje iznad njega i koji se istodobno prepoznaje kao osjetilno par excellence“ (Debord, 1999, 50), a 1984. na vladavini metodama nadzora i prisile, usporedivima s Foucaultovim tumačenjem Benthamova nacrta Panoptikona kao posebna zatvora u kojemu zatočenici nikoga ne mogu vidjeti, ali su od nadređene instancije svi viđeni (Foucault, 1994, 205-210), tada je u Bradburyjevu romanu prisutna sinteza ključnih značajki totalitarizma iz prethodnih dvaju romana: Montag i njegova žena nalaze se u svijetu koji ujedinjuje opresivnost vladajućih - koja se očituje u samome postojanju boraca protiv književne riječi - i hedonistički eshaton realiziran i u ,zidovima salona“ na kojima se projiciraju pokretne slike, pripovijedajući banalne priče u kojima sudjeluju i gledatelji, izgovarajući unaprijed ispisane replike (Bradbury, 2014, 25).

\subsection{Totalitarno poništavanje književnosti: Shakespeare kao prijetnja poretku}

Nadovežemo li se na viđenje svojstava totalitarnosti iz pera Alaina de Benoista kao spoja mesijanstva i manihejstva, kao izraz svjetonazora lišenog nijansi, iznimki i paradoksa, postat će bjelodanim kako u hipersimplificiranosti totalitarnih društava iz svih triju romana nema mjesta ni književnosti kao fluidnoj pojavi i fenomenu otvorenu različitim, nerijetko i proturječnim tumačenjima, $\mathrm{k}$ tome i sredstvu produbljivanja spoznaja te stalnome poticaju misaonih vježbi različitih vrsta. Neuhvatljivost književnoga smisla totalitarizmima je problematična: „Knjige mogu biti takve izdajice! Misliš da te podupiru, a tako ti lako okrenu leđa. I drugi ih mogu upotrijebiti, i eto te, izgubljenog na pustopoljini, u kovitlacu imenica, glagola i pridjeva“ (Bradbury, 2014, 102). Kakav je bio status književnosti u zbiljskim dvadesetostoljetnim totalitarizmima? Dovoljno je tek podsjetiti se na nacionalsocijalističke lomače književnih djela, kao i na nemogućnost sovjetskih autora na objavu pojedinih književnih djela, 
na što se nadovezuje često citirana misao iz posmrtno objavljena romana Mihaila Bulgakova Majstor i Margarita: „Rukopisi ne gore“ (Bulgakov, 1980, 310), koja je mogla poslužiti kao idealan moto Bradburyjevu romanu, gdje ih spaljivači uništavaju plamenom, ali književnost ipak opstaje. U svjetlu totalitarne netrpeljivosti prema književnosti zanimljivo je primijetiti kako se u sva tri proučavana romana pojavljuje ime Williama Shakespearea kao svojevrsna amblema književnosti u cjelini, književnosti per se, barem u zapadnome, napose angloameričkom kontekstu iz kojega izviru i Huxleyjev, Orwellov i Bradburyjev roman.

Načini na koje se u Vrlome novom svijetu, 1984. i Fahrenheitu 451 evocira Shakespeareovo ime su, međutim, vrlo različiti, ono je na najbanalnijoj razini prisutno u Orwellovu romanu, znatno je zastupljenije u Bradburyja, dok najveću važnost - što je očito i iz naslova, koji čini navod iz navodne posljednje Shakespearove drame, Oluje - ima u romanu Aldousa Huxleyja. Shakespeare se, naime, u Orwellovu romanu pojavljuje tek kao simbol staroga svijeta - nakon jednoga pastoralna, idiličnog sna - koji, kao prostor prirode i slobode, predstavlja snažan kontrast mehaniziranoj zbilji u kojoj se čak i književnost proizvodi automatizirano: „Winston se probudio s riječju »Shakespeare« na ustima“" (Orwell, 2008, 35). Fahrenheit 451 i Vrli novi svijet, s druge strane, obiluju aluzijama na Shakespearova djela i citatima iz njegovih drama: u Bradburyjevu se tako romanu spominju naslovi ili navodi iz Hamleta, Mletačkog trgovca, Oluje, Sve je dobro što se dobro svrši i Julija Cezara (Bradbury, 2014, 56, 101, 102 i 110); dok je Huxleyjev fond Shakespearovih djela još obilniji, te - pored Sabranih djela Williama Shakespearea (Huxley, 1988, 146) - uključuje i Oluju, Troila i Kresidu, Romea i Juliju, Antonija i Kleopatru, San Ivanjske noći, Mletačkog trgovca, Othella, Timona Atenjanina, Kralja Leara i Julija Cezara (Huxley, 1988, 154, 160, 171, 174, 181, 188, 210, 212 i 228). Raspravljajući o nemogućnosti razumijevanja šekspirijanskih zapleta u kontekstu Vrloga novog svijeta, Mustafa Mond najjasnije artikulira poništavanje književnosti karakteristično za totalitarizme: „[N]aš svijet nije isti kao Othellov. Nema limuzina bez čelika - i nema tragedija bez društvene nestabilnosti. A svijet je sada stabilan“" (Huxley, 1988, 238). Drugim riječima, cilj totalitarizma iz Huxleyjeve distopije - koji možemo primijeniti i na Orwella i Bradburyja - jest društvo u kojemu književnost poput Shakespeareove, ili književnost općenito, više jednostavno neće biti mogući. 
Borba protiv književnosti u ovim trima romanima slojevita je i u mnogočemu podudarna. S jedne strane, u Fahrenheitu 451 i 1984. ozbiljna su književna djela zamijenjena „trodimenzionalnim pornočasopisima“ (Bradbury, 2014, 59) i ,jeftinom pornografijom“ iz ,sekcije Literarnog komesarijata“ naziva „Pornoodjel“ (Orwell, 2008, 137). S druge strane, u Vrlome novom svijetu sâm život - utemeljen na geslu „Svatko pripada svima“ (Huxley, 1988, 57) - ima sva obilježja „trodimenzionalne“, ,jeftine pornografije“. Pored pornografije, u sva tri romana postoji i alternativna, jeftina književnost za svakodnevnu uporabu, lišena svojega, inače inherentna, subverzivnoga potencijala. U Fahrenheitu 451 knjige se preobražavaju u „skraćene verzije“, „sažete sadržaje“ i - naposljetku - „tabloide“ (Bradbury, 2014, 56). U 1984. književnost se proizvodi u okrilju spomenutog Komesarijata, gdje je stvaraju - „strojevi za pisanje romana“ (Orwell, 2008, 13). Knjige su ondje ,potrošna roba koja se mora proizvoditi kao pekmez ili vezice za cipele“ (Orwell, 2008, 137), a radnje romana slažu se okretanjem kaleidoskopa (,zvalo se to »sklepati fabulu«“ [Orwell, 2008, 111]), dok „opće upute“ izdaje „Planerski komitet“, a „završni retuš“ obavlja „Finalizacijski odjel“" (Orwell, 2008, 137). U Vrlome novom svijetu književnost se svodi na „scenarije za osjetilne predstave“, ,promidžbene krilatice“ i ,hipnopedijske rime“" u sklopu „emocionalnog inženjeringa“ (Huxley, 1988, 82) pučanstva Svjetske Države, a lik Helmholtza Watsona drži predavanja „o upotrebi stihova u moralnoj propagandi i promidžbi“ (Huxley, 1988, 197). Osim hipnopedijom - „,najveć[om] obrazovn[om] i moralizatorsk[om] snag[om]“ (Huxley, 1988, 43), koja označava instalaciju društveno poželjnih misli u dječje umove kroz san - stanovnike se Huxleyjeve distopije odmalena odvikava od sklonosti spram književnosti i pomoću hotimično izazvane traume (Huxley, 1988, 35-36). Knjige su, čini se, prijetnja i iz ekonomske perspektive, pa Huxleyjev Mustafa Mond primjećuje kako ,[n]e može mnogo trošiti onaj koji sjedi uz knjigu i čita je“ (Huxley, 1988, 64), dok Bradburyjev zapovjednik Beatty anuliranje književnosti objašnjava - među ostalim - i tržišnim argumentima: „Što ti je veće tržište, Montag, manje se baviš kontroverzama, upamti to!“ (Bradbury, 2014, 59).

Što se tiče odnosa prema otprije postojećoj književnosti i književnim klasicima, svijet iz Fahrenheita 451 s njima se obračunava na najizravniji - i najprimitivniji - način: represijom. U Bradburyjevoj distopiji, vatrogasci su se s vremenom preobrazili u ,spaljivače“, zadužene za uništavanje 
preostalih književnih djela, skrivenih od vlasti (naslov sama romana dolazi od - kako je naznačeno u podnaslovu - ,temperature na kojoj knjižni papir plane i gori"). „Ponedjeljkom spaljujemo Plath, srijedom Steinbecka, petkom Poea“ (Bradbury, 2014, 15), govori glavni junak, isprva i sâm spaljivač, Guy Montag, da bi na pitanje nisu li spaljivači nekoć spašavali imovinu od vatre, a ne obratno, odgovorio: „Ne. Kuće su oduvijek bile otporne na vatru, vjeruj mi na riječ“ (Bradbury, 2014, 15). Kao što stoji u njihovu priručniku, spaljivači su osnovani 1790. godine, s ciljem „da spaljuju knjige s engleskim utjecajem u kolonijama“, a njihov utemeljitelj je, tobože, Benjamin Franklin (Bradbury, 2014, 38). Oni su i ,cenzori, suci i izvršitelji“", koji su, nakon što su vatrogasci ostali bez posla, dobili zaduženje „skrbnika“ za svačiji „duševni mir“ (Bradbury, 2014, 60). U Vrlome novom svijetu, u sklopu „kampanje protiv prošlosti“, zabranjene su sve knjige tiskane ,prije 150. godine F. E.“, što znači - od dana „kad je na tržište izbačen prvi model T Našega Forda“, povijesnog izumitelja Henryja Forda (1863.-1947.), kojega se u Huxleyjevu romanu poima kao mesijansku figuru prema kojoj je ,imenovan [...] početak nove ere“ (Huxley, 1988, 66). U 1984. su pak „lov na knjige i njihovo uništavanje“ bili obavljeni toliko „temeljito“ da je bilo, ,jako malo vjerojatno da igdje u Oceaniji postoji primjerak knjige objavljene prije 1960.“(Orwell, 2008, 104). U skladu s time riječ „knjiga“ se u Orwellovoj distopiji mogla odnositi samo na jednu knjigu - Teoriju i praksu oligarhijskoga kolektivizma stvarna ili izmišljenog disidenta Emmanuela Goldsteina, koju Winston Smith uspijeva nakratko posjedovati te djelomice i pročitati (Orwell, 2008, 193).

Pored stvaranja novih, protuknjiževnih djela i represije nad književnošću, treća dimenzija transformacije društvena odnosa prema književnosti - a koja se, zanemarimo li navadu već naznačena prekomjernog sažimanja književnih djela u Fahrenheitu 451, pojavljuje jedino u Orwella - predstavlja preispisivanje postojećih klasika, isprva u skladu s partijskim načelima, a potom s planom deliterarizacije književnosti kroz njihovu preobrazbu ili „prijevod“ s izvorna oblika na novi jezik sastavljen od kratica, koji skučenošću svojeg vokabulara, na vitgenštajnovskom tragu ${ }^{5}$, proizvodi i ne-

${ }^{5}$ Miroslav Beker u svojemu pogovoru Orwellovu romanu naslovljenom 1984. - tjeskobe suvremenog čovjeka podsjeća na Wittgensteinovu misao po kojoj su ,granice našega jezika ujedno i granice našega svijeta" (Orwell, 2008, 330). 
mogućnost kritičkoga mišljenja, a ime mu je „novozbor“. Smisao toga jezika nije poticati misao, nego je zatrti, čime se posredno onemogućava i komunikacija, kao ostvarenje temeljne funkcije jezika, pa bismo ga mogli prozvati - kao i književnost koja potire književni smisao protuknjiževnošću - antijezikom. Prvi slučaj oprimjeruje nezgoda režimskoga pjesnika Amplefortha, kojega Winston potkraj romana susreće u pritvoru u Ministarstvu ljubavi. „Pripremali smo definitivno izdanje Kiplingovih pjesama“, pojasnio je Ampleforth razloge svojega pada u nemilost. „Dopustio sam da na kraju jednog stiha ostane riječ «Bog». Nisam mogao drukčije! [...] Znaš li ti koliko u cijelom našem jeziku ima rima na «rog», a nijedna mi nije pristajala u pjesmu“ (Orwell, 2008, 241), pojadao se Winstonu. Drugi slučaj znatno je slojevitiji, a dio je širega plana zamjene engleskoga jezika kakav poznajemo njegovom novom inačicom: „Do 2050., i ranije vjerojatno, svako realno znanje starozbora će se izgubiti. Sva literatura prošlosti bit će uništena. Chaucer, Shakespeare, Milton, Byron - postojat će samo u novozbornim verzijama, ne samo izmijenjeni u nešto drugo već izmijenjeni u nešto doslovno suprotno od onoga što su nekoć bili“" (Orwell, 2008, 58). Takva nakana je, dakako, nedvojbeno perfidnija, ali i učinkovitija u uništavanju književnosti od pukoga spaljivanja preostalih knjiga.

Nada, međutim, u ovim trima romanima ipak postoji. Utemeljena u regenerativnoj moći pisane (umjetničke) riječi, ona se u Orwella i Bradburyja očituje slično, dok kod Huxleyja književnost preživljava isključivo u okviru zakonodavca koji se oglušuje o zakon, ali ga nitko ne može kontrolirati. „[P]ošto ja ovdje provodim zakon, ja ga isto tako mogu i kršiti“, odgovara Mustafa Mond na pitanje o svojoj upoznatosti sa Shakespeareovim dramskim opusom (Huxley, 1988, 236), a slično je i u Fahrenheitu 451, gdje se književnim navodima najviše poslužuje upravo zapovjednik spaljivača knjiga, Beatty ${ }^{6}$. Najizravniji se, međutim, izraz eventualnog spasenja i apoteoze književnosti krije na završetku Bradburyjeva romana kada Montag nailazi na skupinu lutalica koji sadržaje izgubljenih djela mogu reproducirati u cijelosti, zatvarajući time krug s počecima književne umjetnosti kao izvorno usmenog fenomena: „Byron, Tom Paine, Macchiavelli

${ }^{6}$ Beattyjeva načitanost može se iščitati i iz njegova citiranja Shakespearea, Philipa Sidneyja, Alexandera Popea, Samuela Johnsona, Thomasa Dekkera, Bena Jonsona, Roberta Burtona i Paula Valéryja (Bradbury, 2014, 100-102). 
ili Krist, sve je ovdje“ (Bradbury, 2014, 137). Kakva je onda perspektiva? „[K]ad rat završi, jednoga dana, jedne godine, knjige će ponovno moći biti zapisane, ljudi će biti pozivani, jedan po jedan, i recitirat će što znaju pa ćemo to sve imati tiskano do novog Mračnog doba, kad ćemo morati sve to raditi ispočetka“" (Bradbury, 2014, 138-139). Slična vjera u neuništivost istinske književne riječi - pa makar ona i ne bila umjetničkog, već znanstvenoga ili publicističkog tipa - počiva i u Orwellovoj 1984., premda se ondje odnosi samo na jednu knjigu, onu Goldsteinovu: „Knjiga je neuništiva. Čak i da posljednji primjerak nestane, mi bismo je mogli reproducirati gotovo od riječi do riječi“" (Orwell, 2008, 186). Činjenica da te riječi izgovara prijetvorni član Uže Partije O'Brien ne mijenja na stvari - da su one istinite osjeća i sâm Winston, kada nakon čitanja ulomaka iz Teorije i prakse oligarhijskog kolektivizma ustanovljuje kako u njoj ne piše ništa čega već otprije nije bio svjestan (Orwell, 2008, 186). Na Orwellovu i, posebice, Bradburyjevu viziju prirodno se nadovezuju riječi s posljednjega Borgesova javnoga istupa, istaknute i u motu ovoga rada: „Kad bi se spalile sve knjige, sve što se do sada napisalo, čovjek bi ih napisao još bolje“.

\section{Totalitarnost i dobrovoljno ropstvo, književnost i demokracija}

U svim trima problematiziranim i analiziranim romanima književnost je sredstvo otpora totalitarnosti te, pojmimo li demokratičnost u skladu s Rancièreovom definicijom, oruđe demokratičnosti. Književnost se u navedenim romanima poima kao nepoželjno drugo (treće, četvrto...) mišljenje u odnosu na ono što je propisano, ali i kao kategorija koju se ne može jednoznačno odrediti, o čemu lamentira i spaljivački kapetan Beatty (,Knjige mogu biti takve izdajice!“). Mjerljiva isključivo sobom samom, onime što se u tradiciji ruskoga formalizma naziva „literarnošću“, to jest onime po čemu književnost jest to što jest (cf. Solar, 1980, 213), književnost predstavlja prijetnju jednoumlju, koja se samom svojom naravi udaljuje od konsenzualne demokratičnosti koja završava u totalitarizmu, približavajući se Rancièreovu viđenju demokracije kao vječne anarhije, s različitim stupnjevima suglasja i nesuglasja, od jednoga trenutka do drugog, u kojemu je sve opet podložno promjeni, kao u različitim čitanjima 
istih književnih djela. U književnim distopijama književnost se tretira onako kako se u zbiljskim dvadesetostoljetnim totalitarizmima tretiralo stvarnost: kao element otvoren interpretacijama koji se, u ime jedinstva, nužno mora svesti na jednodimenzionalnost od koje se neće odstupiti.

U svojemu pismu Orwellu Huxley podsjeća na robove koji „,vole svoje robovanje“, preduvjet čega je, među ostalim - sudeći po njezinu statusu u Vrlome novom svijetu, ali i 1984. i Fahrenheitu 451 - i poništavanje književnosti. O fenomenu robova koji „vole svoje robovanje“ u svojoj Raspravi o dobrovoljnome ropstvu pisao je Étienne de La Boétie, ne anticipirajući samo Huxleyjevu distopiju već i Arendtinu viziju pristajanja kolektiva na totalitarno jednoumlje:

Ako se tisuću, ako se milijun ljudi, tisuću gradova ne brani od jednog čovjeka, nije to plašljivost. [...] Taj koji vas je ukrotio nema nego dva oka, dvije ruke, jedno tijelo i ništa više [...] osim nadmoći koju mu vi dajete da bi vas uništio. Odakle njemu tolike oči kojima vas uhodi, ako ne od vas? Kako to da ima tolike ruke za udarce, ako ih ne uzima od vas? [...] Budite odlučni da više nećete robovati, i slobodni ste (Boétie, 2017, 13-14).

Njegove riječi kao da je evocirao i Orwell kada je Winstonovom rukom napisao, referirajući se na „prole“, oceanijsku inačicu proletera, niže klase neučlanjene u Partiju:

Ako ima nade, [...] ona je u prolima. Ako ima nade, ona mora biti u prolima, jer se jedino tamo, u nepreglednim rojevima zaboravljenih masa koje čine 85 postotaka Oceanije, može roditi snaga koja će prevladati Partiju. Partija se ne može srušiti iznutra. [...] Ali proli, kad bi samo nekako mogli postati svjesni vlastite snage, ne bi trebali kovati nikakve urote. Trebali bi se samo dići i stresti kao konj koji otresa muhe. Ako im se prohtije, mogu sutra ujutro rastjerati Partiju kao pljevu (Orwell, 2008, 75).

Ovaj ulomak primjenjiv je i na stanovnike distopijskih svjetova iz Huxleyjeva i Bradburyjeva pera - njima se ne vlada silom, već slojevitim mehanizmom naizmjenične i simultane ugode i prisile. On je oprečan slobodi, jer se ne temelji na pluralnosti izbora, nego na manipulaciji mogućnostima i njihovu svođenju na jedan, društveno poželjan obrazac, a koji u svim trima romanima rezultira fenomenom ,dobrovoljna ropstva“. Književnost je stoga u njima samo jedna od kategorija koje se, poput slobode izbora, sustavno zatiru. Iz toga proizlazi da književnost i sloboda imaju nešto zajedničko. Pojmimo li demokratičnost kao politološki ekvivalent 
konceptu slobodne volje, ili - Rancièreovim riječima - ,anarhiju“ koja znači ,da nema grupe koja polaže pravo da vlada, koja je ovlaštena da vlada“ (Rancière, 2016), književnost, koja svojom „otvorenošću“ novim čitanjima predstavlja sličnu vrstu interpretativnog kaosa, služi i kao sredstvo procjene slobodarskog stupnja svake vlasti: iz Vrloga novog svijeta, 1984. i Fahrenheita 451 možemo iščitati da će svaki režim stvarnost tretirati otprilike onako kako tretira i književnost, kao mehanizam onemogućavanja „dobrovoljnoga ropstva“ na kolektivnoj, sveobuhvatnoj razini.

\section{Literatura}

Otk - Knjiga otkrivenja. U: Biblija. (1994). Prev. Lj. Rupčić. Zagreb: Kršćanska sadašnjost.

Arendt, H. (1996). Totalitarizam. Prev. M. Paić Jurinić. Zagreb: Politička kultura.

Atwood, M. (2007). Everybody is happy now. „Guardian“. https://www.theguardian. com/books/2007/nov/17/classics.margaretatwood. 20.02.2019.

Atwood, M. (1988). Sluškinjina priča. Prev. N. Paravić. Zagreb: Globus.

Beker, M. (2008). 1984. - tjeskobe suvremenog čovjeka. U: G. Orwell. 1984. Zagreb: Alfa, str. 325-337.

Benoist, A. de (2005). Komunizam i nacizam: 25 ogleda o totalitarizmu u 20. stoljeću (1917.-1989.). Prev. I. Barišić. Zagreb: Naklada Hasanbegović.

Benson, R. H. (2016). Gospodar svijeta. Prev. A. M. Chwalowsky. Split: Verbum.

Bloom, H. (2003). Introduction. U: Bloom's Modern Critical Views: Aldous Huxley. New York: Chelsea House Publishers.

Bloom, H. (2007). Introdution. U: Bloom's Modern Critical Views: George Orwell. New York: Chelsea House Publishers.

Boétie, É. La (2017). Rasprava o dobrovoljnom ropstvu. Prev. M. Spajić. Zagreb: Meandar Media.

Borges, J. L. (1997). Posljednje Borgesovo predavanje. Prev. J. Hećimović Nikšić. „Hrvatsko slovo" br. 100.

Bradbury, R. (2014). Fahrenheit 451. Prev. A. Majnarić. Zagreb: Algoritam.

Bulgakov, M. (1980). Majstor i Margarita. Prev. V. Flaker. Zagreb: Sveučilišna naklada Liber.

Debord, G. (1999). Društvo spektakla \& komentari društvu spektakla. Prev. G. Vujasinović. Zagreb: Arkzin.

Eliot, T. S. (2009). Ideja kršćanskog društva. U: Pusta zemlja i druga djela. Prev. G. Vujasinović. Zagreb: Školska knjiga, str. 390-425.

Foucault, M. (1994). Nadzor i kazna: Rađanje zatvora. Prev. D. Marion. Zagreb: Informator - Fakultet političkih znanosti.

Fromm, E. (1983). Afterword. U: G. Orwell: 1984. New York: Penguin Putnam Inc., str. 280-292. 
Girard, R. (2003). Dvojnici i individualnost. Prev. A. Stamać. „Republika: mjesečnik za književnost, umjetnost i društvo" br. 59, str. 72-78.

Gottlieb, E. (2001). Dystopian Fiction East and West: Universe of Terror and Trial. Quebec City: McGill-Queens's University Press.

Huxley, A. (1998). Vrli novi svijet. Prev. S. Vidmar. Zagreb: Izvori.

Huxley, A. (2015). Huxley to Orwell: My Hellish Vision of the Future is Better Than Yours (1949). „Open Culture“. http://www.openculture.com/2015/03/huxley-toorwell-my-hellish-vision-of-the-future-is-better-than-yours.html. 30.11.2018.

Orwell, G. (2008). 1984. Prev. A. Šoljan. Zagreb: Alfa.

Platon (1997). Država. Prev. M. Kuzmić. Zagreb: Naklada Jurčić.

Popper, K. (2003). Otvoreno društvo i njegovi neprijatelji. Sv. 1. Prev. D. Karaman. Zagreb: Kruzak.

Pynchon. T. (2003) Pynchon on Orwell. „Arthur“. https://arthurmag.com/2005/01/22/ pynchon-on-orwell/. 20.02.2019. (Izvorno „Guardian“).

Rancière, J. (2008). Mržnja demokracije. Prev. L. Kovačević. Zagreb: Naklada Ljevak.

Rancière, J. (2016). Ne postoji ključ za budućnost. Razgovarala T. Okić. „Novosti““. https://www.portalnovosti.com/jacques-ranciere-ne-postoji-kljuc-za-buducnost. 20.2.2019.

Solar, M. (2003). Povijest svjetske književnosti. Zagreb: Golden marketing.

Solar, M. (1980). Teorija književnosti. Zagreb: Školska knjiga.

Zamjatin, J. (2003). Mi. Prev. R. Božić Šejić. Zagreb: Naklada Breza. 